\title{
New genomics studies to understand the link between nontyphoidal Salmonella bacteremia and gastroenteritis in Africa
}

\author{
Robert S. Onsare ${ }^{1,2,3}$, Calman A. MacLennan ${ }^{3,4}$ \\ ${ }^{1}$ Centre for Microbiology Research, Kenya Medical Research Institute, Nairobi, Kenya \\ 2 Jomo Kenyatta University of Agriculture and Technology, Nairobi, Kenya \\ ${ }^{3}$ Novartis Vaccines Institute for Global Health, Siena, Italy \\ ${ }^{4}$ MRC Centre for Immune Regulation, School of Immunity and Infection, College of Medicine and Dental Sciences, \\ University of Birmingham, Birmingham, United Kingdom
}

Key words: nontyphoidal Salmonella; bacteremia; diarrhea; whole genome sequencing; genomics

J Infect Dev Ctries 2014; 8(2):252-253. doi:10.3855/jidc.4377

(Received 03 November 2013 - Accepted 29 January 2014)

Copyright $($ C 2014 Onsare et al. This is an open-access article distributed under the Creative Commons Attribution License, which permits unrestricted use, distribution, and reproduction in any medium, provided the original work is properly cited.

Dear Editor - Nontyphoidal Salmonellae (NTS) are attracting increasing attention as a cause of invasive disease among African children and HIVinfected individuals [1-4]. However, these invasive (hence iNTS) infections continue to cause confusion, partly because of the contrasting clinical presentations of NTS disease in high- and low-income countries [4]. NTS in US and Europe normally cause self-limiting gastroenteritis [5]. In sub-Saharan Africa, they cause bacteremia [2] with symptoms of gastroenteritis in under half of patients [1]. Case fatality rates for NTS bacteremia are 20-25\%, multidrug resistance is increasing, and no vaccine is available $[1,4]$.

Understanding iNTS disease in Africa is hindered by our limited knowledge of diarrheal NTS and its relationship to invasive disease. Better characterisation of African diarrheagenic isolates and comparison with invasive ones would help us understand whether the same strains are responsible for both clinical presentations or whether invasive disease is the consequence of different, potentially more virulent clades of NTS. This would also provide valuable insight into routes of transmission. Since healthcare resources and services in the continent have to be prioritised for the treatment of the most critically-ill patients, more is known about iNTS disease than NTS diarrhea. Microbiological facilities are limited, so few data exist on contemporaneous presence of NTS in stool and blood. Where blood culturing occurs, stool cultures are rare, and vice versa. This does not preclude Salmonella in blood of patients with NTS diarrhea nor NTS in the gastrointestinal tract of those with iNTS disease.

S. Typhimurium and Enteritidis, are responsible for most iNTS cases in Africa [1,2] and confusingly around 50\% of NTS gastroenteritis in the US [5]. It is unclear why iNTS is so common in Africa. Possible explanations include differences in immunity, virulence, hygiene and transmission [4]. Recent whole genome sequencing (WGS) studies demonstrate that invasive African $S$. Typhimurium is genetically distinct [6], belonging to a new MLST type, ST313. This is characterized by marked genome degradation [7] and has spread throughout the continent [3]. Studies on the genotype/phenotype relationship of ST313, and the genomes of invasive African $S$. Enteritidis, are awaited.

The Global Enteric Multicenter Study provides important insights into diarrhea etiology in developing countries [8]. Of the four African sites, NTS only significantly associated with diarrhea in Kenya, possibly because of high levels of NTS in control subjects elsewhere. Of concern, a diarrhea study from Western Kenya found NTS in stool significantly associated with mortality. Most isolates were serovar Typhimurium or Enteritidis [9]. Neither study investigated bacteremia nor genotype, so it is unknown whether S. Typhimurium were ST313. In a Nairobi study comparing invasive and gastrointestinal NTS 
isolates from hospitalized children, $S$. Typhimurium and Enteritidis again accounted for most isolates [10]. Pulsed-field gel electrophoresis (PFGE) detected no difference between invasive and gastrointestinal isolates. However, PFGE has limited ability to discriminate genetic differences compared with WGS.

Understanding the relationship between African invasive and diarrheagenic NTS disease requires new studies that recruit patients with bacteremia and gastroenteritis, investigate the presence of NTS in blood and stool of all participants, and use WGS to characterize isolates. Another approach to the genetic characterisation and discrimination of NTS isolates is transcriptomics [11]. Transcriptomics is complementary to WGS and can lead towards improved insight into how genetic differences relate to function. There is currently little evidence to support zoonotic transmission of NTS in Africa [12] and parallel studies to identify any environmental reservoirs of NTS are needed. Until such studies happen, understanding the pathogenesis and transmission of African NTS disease, and our ability to develop new interventions to improve clinical management, will remain limited.

\section{Acknowledgements}

This work was supported by a European Union FP7 Industry and Academia Partnerships and Pathways award, GENDRIVAX (Genome-driven vaccine development for bacterial infections). This is a collaboration between the Novartis Vaccines Institute for Global Health, Kenyan Medical Research Institute, Wellcome Trust Sanger Institute and Swiss Tropical and Public Health Institute [grant number 251522].

\section{References}

1. Feasey NA, Dougan G, Kingsley RA, Heyderman RS, Gordon MA (2012) Invasive non-typhoidal salmonella disease: an emerging and neglected tropical disease in Africa. Lancet 379: 2489-99.

2. Reddy EA, Shaw AV, Crump JA (2010) Community-acquired bloodstream infections in Africa: a systematic review and meta-analysis. Lancet Infect Dis 10: 417-32.

3. Okoro CK, Kingsley RA, Connor TR, Harris SR, Parry CM, Al-Mashhadani MN, Kariuki S, Msefula CL, Gordon MA, de Pinna E, Wain J, Heyderman RS, Obaro S, Alonso PL, Mandomando I, MacLennan CA, Tapia MD, Levine MM, Tennant SM, Parkhill J, Dougan G (2012) Intracontinental spread of human invasive Salmonella Typhimurium pathovariants in sub-Saharan Africa. Nat Genet 44: 1215-21.

4. MacLennan CA, Levine MM (2013) Invasive nontyphoidal Salmonella disease in Africa: current status. Expert Rev Anti Infect Ther 11: 443-6.

5. Hohmann EL (2001) Nontyphoidal salmonellosis. Clin Infect Dis 32: 263-9.
6. Wain J, Keddy KH, Hendriksen RS, Rubino S (2013) Using next generation sequencing to tackle non-typhoidal Salmonella infections. J Infect Dev Ctries 7: 1-5. doi:10.3855/jidc.3080

7. Kingsley RA, Msefula CL, Thomson NR, Kariuki S, Holt KE, Gordon MA, Harris D, Clarke L, Whitehead S, Sangal V, Marsh K, Achtman M, Molyneux ME, Cormican M, Parkhill J, Maclennan CA, Heyderman RS, Dougan G (2009) Epidemic multiple drug resistant Salmonella Typhimurium causing invasive disease in sub-Saharan Africa have a distinct genotype. Genome Res 19: 2279-87.

8. Kotloff KL, Nataro JP, Blackwelder WC, Nasrin D, Farag $\mathrm{TH}$, Panchalingam S, Wu Y, Sow SO, Sur D, Breiman RF, Faruque AS, Zaidi AK, Saha D, Alonso PL, Tamboura B, Sanogo D, Onwuchekwa U, Manna B, Ramamurthy T, Kanungo S, Ochieng JB, Omore R, Oundo JO, Hossain A, Das SK, Ahmed S, Qureshi S, Quadri F, Adegbola RA, Antonio M, Hossain MJ, Akinsola A, Mandomando I, Nhampossa T, Acacio S, Biswas K, O'Reilly CE, Mintz ED, Berkeley LY, Muhsen K, Sommerfelt H, Robins-Browne RM, Levine MM (2013) Burden and aetiology of diarrhoeal disease in infants and young children in developing countries (the Global Enteric Multicenter Study, GEMS): a prospective, case-control study. Lancet 382: 209-22.

9. O'Reilly CE, Jaron P, Ochieng B, Nyaguara A, Tate JE, Parsons MB, Bopp CA, Williams KA, Vinje J, Blanton E, Wannemuehler KA, Vulule J, Laserson KF, Breiman RF, Feikin DR, Widdowson MA, Mintz E (2012) Risk factors for death among children less than 5 years old hospitalized with diarrhea in rural western Kenya, 2005-2007: a cohort study. PLoS Med 9: e1001256.

10. Kariuki S, Revathi G, Kariuki N, Kiiru J, Mwituria J, Hart CA (2006) Characterisation of community acquired nontyphoidal Salmonella from bacteraemia and diarrhoeal infections in children admitted to hospital in Nairobi, Kenya. BMC Microbiol 6: 101.

11. Kroger C, Dillon SC, Cameron AD, Papenfort K, Sivasankaran SK, Hokamp K, Chao Y, Sittka A, Hebrard M, Handler K, Colgan A, Leekitcharoenphon P, Langridge GC, Lohan AJ, Loftus B, Lucchini S, Ussery DW, Dorman CJ, Thomson NR, Vogel J, Hinton JC (2012) The transcriptional landscape and small RNAs of Salmonella enterica serovar Typhimurium. Proc Natl Acad Sci U S A 109: E1277-E1286.

12. Kariuki S, Revathi G, Kariuki N, Kiiru J, Mwituria J, Muyodi J, Githinji JW, Kagendo D, Munyalo A, Hart CA (2006) Invasive multidrug-resistant non-typhoidal Salmonella infections in Africa: zoonotic or anthroponotic transmission? J Med Microbiol 55: 585-91.

\section{Corresponding author}

Professor Calman A. MacLennan

Novartis Vaccines Institute for Global Health,

Via Fiorentina 1, 53100 Siena, Italy.

$\mathrm{T}+390577539240$

F +390577 243352

Email: calman.maclennan@novartis.com

Conflict of interests: CAM is an employee of the Novartis Vaccines Institute for Global Health and the recipient of a clinical research fellowship from GlaxoSmithKline. 